\title{
Pretransplant clinicopathological correlation in end-stage primary pulmonary hypertension
}

\author{
B.P. Madden*†, J. Gosney**, J.G. Coghlan*, K. Kamalvand*, \\ A.W. Caslin**, P. Smith**, M. Yacoub*+, D. Heath**
}

Pretransplant clinicopathological correlation in end-stage primary pulmonary hypertension. B.P. Madden, J. Gosney, J.G. Coghlan, K. Kamalvand, A.W. Caslin, P. Smith, M. Yacoub, D. Heath. CERS Journals Ltd 1994.

ABSTRACT: The aim of the study was to see if there was any correlation between the histopathology, ultrastructure, pulmonary endocrinology and clinical manifestations of end-stage primary pulmonary hypertension.

Twenty patients undergoing heart-lung transplantation for the disease were studied. The nature and duration of symptoms and signs, results of haematological, electrocardiographic, radiographic, echocardiographic and haemodynamic studies, and the response of patients to vasodilators were compared with data from histopathological and ultrastructural study of lungs removed at transplantation.

Length of clinical history and clinical evidence of severe disease were not necessarily associated with advanced histopathology, nor did the presence of small, contracted muscular pulmonary arteries imply responsiveness to vasodilators. Numbers of gastrin-releasing peptide-containing pulmonary endocrine cells were greater in lungs in which there was activity of myofibroblasts in pulmonary arterial vessels, and correlated negatively with mean pulmonary artery pressure and pulmonary artery systolic pressure.

Whereas the prognosis of primary pulmonary hypertension cannot as yet be defined by other than its clinical manifestations, intimal proliferation as well as vasoconstriction may be important in its pathogenesis. The release of gastrinreleasing peptide from pulmonary endocrine cells may possibly be involved in this process.

Eur Respir J., 1994, 7, 672-678.

\begin{abstract}
*Harefield Hospital, Harefield, Middlesex, UK. Royal Brompton National Heart \& Lung Hospital, London, UK. **Dept of Pathology, University of Liverpool, Liverpool, UK.
\end{abstract}

\section{Correspondence: B. Madden}

Dept of Cystic Fibrosis

Royal Brompton National Heart and Lung Hospital

Sydney Street

London SW3 6NP

UK

Keywords: Gastrin-releasing peptide lung

plexiform arteriopathy

primary pulmonary hypertension

pulmonary endocrine cells

Received: November 131992

Accepted after revision November 211993
In primary pulmonary hypertension $(\mathrm{PPH})$, the classical pathological finding is plexogenic pulmonary arteriopathy [1-3]. This is characterized by a triad of plexiform lesions (which are its hallmark), concentric laminar ("onion-skin") proliferation, and fibrinoid necrosis. In the early stages of the condition, however, the changes are much more subtle, and involve migration of transformed myocytes from their original location in the inner half of the media of involved muscular arteries through the internal elastic lamina into the intima, where they assume the characteristics of myofibroblasts and proliferate. This situation represents the "preplexiform" phase of plexogenic pulmonary arteriopathy. As plexiform lesions mature, they become fewer, smaller and less cellular, and undergo progressive fibrosis.

Although the histopathology [2-5], ultrastructure [6, 7], pulmonary endocrinology [8,9], and clinical manifestations [1, 10,11], of the condition have been described, their correlation has not been closely studied. The heartlung transplantation programme at Harefield Hospital has provided a unique opportunity to correlate the clinical and pathological features in a single population of patients with end-stage primary pulmonary hypertension.
The aim of this study was to assess whether the clinical features (mode of presentation, rate of progression and physical findings), the severity of pulmonary hypertension and the response to vasodilator therapy correlated with the pathological findings in the lungs removed at transplantation.

\section{Patients and material}

\section{General details}

Twenty consecutive patients with $\mathrm{PPH}$, who underwent heart-lung transplantation at Harefield Hospital, Middlesex, UK, were studied. There were 14 females and 6 males, with a mean age of $26 \mathrm{yrs}(2-51 \mathrm{yrs})$ at the time of transplantation. From a review of their preoperative notes (including those of the referring centre), all pertinent clinical data were retrieved, including clinical history, nature and duration of symptoms, physical findings at preoperative examination, and results of routine preoperative haematological and biochemical investigations. 


\section{Cardiological studies}

These included electrocardiography, chest radiography and an echocardiogram. Cardiac catheterization was performed in 18 of the 20 patients within 2 yrs of operation. Using two dimensional echocardiography, a scoring system was used to stratify patients according to relative right and left ventricular sizes. Grade 1 described the normal heart with left ventricular dimensions exceeding those of the right ventricle; in grade 2 the right ventricular dimensions approximated to those of the left; and grade 3 described compression of the left ventricle by the right. Ideally, these hearts would have been examined after removal, but this was impossible as all were used for further transplantation.

\section{Response to vasodilators}

Response to vasodilators was assessed, a favourable response being defined as a $>30 \%$ reduction in pulmonary vascular resistance, with a $>20 \%$ increase in cardiac output. No patient had been on long-term vasodilator therapy preoperatively.

\section{Pathological studies}

At operation, pulmonary tissue was removed and prepared for histopathological and ultrastructural examination. Between 5 and 12 blocks of tissue were taken from each pair of lungs and embedded in paraffin wax. One millimetre cubes of tissue were taken for electron microscopy. These pathological studies were performed in the absence of knowledge of the pretransplant clinical diagnosis.

Study of pulmonary endocrine cells. Sections were cut at $4 \mu \mathrm{m}$ and labelled by the peroxidase-anti-peroxidase (PAP) method using polyclonal primary antisera raised in rabbit to calcitonin (Dako, Bucks, UK) and gastrinreleasing peptide (GRP) (Cambridge Research Biochemicals, Altrincham, UK) at a dilution of 1:4,000. These are the two peptides most prevalent in adult human pulmonary endocrine cells [12]. Incubation was for 18 $\mathrm{h}$ at constant humidity and a temperature of $4^{\circ} \mathrm{C}$. Each primary antiserum was linked to PAP complex (Dako) diluted 1:100 by swine anti-rabbit serum (Dako) diluted 1:50. Both of these stages were performed at room temperature, with incubation lasting for $30 \mathrm{~min}$. The chromogen was 3-amino-9-ethyl carbazole.

Liquid phase absorption studies were performed for calcitonin and GRP, in which increasing amounts of antigen were added to $1 \mathrm{ml}$ aliquots of antiserum at increasing dilution and incubated for $18 \mathrm{~h}$ at $4^{\circ} \mathrm{C}$. Addition of the appropriate antigen at a concentration of $25 \mathrm{ng} \cdot \mathrm{ml}^{-1}$ of antiserum quenched all staining, as tested by the use of tissue section controls. The tissue control for calcitonin was a section of a human medullary carcinoma of the thyroid. That for GRP was a section of human foetal lung.

An assessment of the number of immunoreactive cells containing the two peptides was made by counting their number and expressing it per square centimetre of tissue section as measured by planimetry. Although this method has been used frequently in the past, the most accurate way of quantifying numbers of pulmonary endocrine cells is to express them in terms of the total epithelial population (e.g. endocrine cells per 10,000 epithelial cells) or, more simply, in terms of epithelial length (e.g. endocrine cells per $10 \mathrm{~cm}$ of epithelium) [12].

However, with collapsed lung, crenation of the smaller airways occurs and the accuracy gained by application of these methods of quantification is largely lost, especially if attempts are made to express endocrine cells per 10,000 epithelial cells, when the calculation of the number of epithelial cells per unit length of epithelium is impossible to carry out with accuracy. Neither does this approach permit quantification of parenchymal endocrine cells which, although very sparse in normal human lungs, often appear in pulmonary disease [12].

In view of these problems, and since the tissue we had for study was unavoidably collapsed, we considered that no benefit would be gained by attempting to apply such methods of quantification. In addition, and most importantly, we knew from previous studies on these diseased lungs that clusters of endocrine cells were to be seen not only in airways, but also in alveoli, a location which would prevent their quantification in terms of epithelial length or of the total epithelial population.

The majority of the airways in the tissue studied were terminal and respiratory bronchioles with few intrapulmonary bronchial branches; there were no extrapulmonary airways at all. The area of each section occupied by airways was $14 \pm 4 \%$ of its total area, so that, despite the structural heterogeneity of the lung, careful sampling meant that there was little variation in the proportion of the different components of the lung in the blocks taken for study.

For the purposes of comparison, these data were compared with endocrine cell counts in two groups of four age- and sex-matched controls, who were dying with no evidence of cardiopulmonary disease.

Histopathology and ultrastructural studies. Sections stained with haematoxylin and eosin, an elastic and van Gieson method and for the Perl's Prussian blue reaction were studied, and the following features were noted or measured; presence and nature of plexiform lesions; the nature of intimal proliferation in muscular pulmonary arteries; the presence and characterization of muscularized arterial vessels $<80 \mu \mathrm{m}$ in diameter; the presence of thrombi in muscular pulmonary arteries; the severity of atherosclerosis in elastic pulmonary arteries; the percentage intimal obstruction in pulmonary veins; and the presence of haemorrhage or infarction. Finally, ultrathin sections were examined by electron microscopy as described previously $[6,7]$ for evidence of muscular evaginations, a marker of vasoconstriction in animals [13].

\section{Statistical methods}

Comparisons between the presence or absence of myofibroblasts and the numbers of pulmonary endocrine cells 
immunoreactive for GRP and calcitonin were made using the Mann-Whitney U-test, appraised one-tailed. Clinicopathological correlations were assessed using multivariate regression analysis.

\section{Results}

\section{Clinical presentation}

The natural history of the condition showed remarkable variability. At one extreme, a male patient with familial primary pulmonary hypertension presented acutely and deteriorated rapidly, requiring urgent transplantation within 5 months. At the other extreme, a female patient presented with haemoptysis $17 \mathrm{yrs}$ before the gradual progression of her condition necessitated transplantation. The mean duration of symptoms was $5 \mathrm{yrs}$ at the time of transplantation and the course was considered aggressive ( $\leq 2 \mathrm{yrs}$ ) in nine patients, and benign $(\geq 10 \mathrm{yrs}$ ) in four (table 1$)$.

Dyspnoea on exertion was the commonest presenting symptom, occurring in 17 patients. Associated presenting symptoms included cyanosis on exertion in six patients, general malaise in two, chest pain in two, and haemoptysis and syncope in one patient each. Dyspnoea developed in all subjects during the course of their illness, and clinical progression of the disease was clearly associated with increasing dyspnoea. Cyanosis occurred in 15 patients, initially being exertional only, i.e. developing only when exercised on a treadmill, but becoming fixed (i.e. present at rest) in 13 prior to transplantation. Chest pain was a feature in eight patients, and four of these described chest pain on exertion. Presyncope was reported by five patients, and recurring syncope occurred in three. Haemoptysis, abdominal pain and malaise were each described by two patients.

\section{Physical findings}

In order of frequency, the following findings were evident at the pre-operative examination: a loud pulmonary component of the second heart sound in all; parasternal heave in 19; fixed cyanosis in 13; elevated jugular venous pressure in 13; pulsatile hepatomegaly in 11; right ventricular gallop in 11; ankle oedema in 9 and ascites in 5 (table 1).

Associated conditions included Raynaud's phenomenon in two patients (cases No. $5 \& 7$ ), systemic lupus erythematosus (case No. 5), hyperprolactinaemia (case No. 4) and systemic hypertension (case No. 19). One patient had familial primary pulmonary hypertension (case No. 20).

\section{Laboratory investigations}

Haematological and biochemical. The full blood count was normal in all but two patients, both of whom had polycythaemia (case No. $3 \mathrm{Hb} 17 \mathrm{~g} \cdot \mathrm{dl}^{-1}$; case No. $5 \mathrm{Hb}$ $\left.18 \mathrm{~g} \cdot \mathrm{dl}^{-1}\right)$. Indices of renal function were normal in 16 ; the urea was between 7 and $10 \mathrm{mmol} \cdot l^{-1}$ in the remaining four; and the creatinine level was $170 \mu \mathrm{mol} \cdot l^{-1}$ in one patient (case No. 12). Serum bilirubin and hepatic enzymes were normal in eight patients, with minor abnormalities in all patients with right heart failure (mean bilirubin $34 \mu \mathrm{mol} \cdot l^{-1}$ ) and hepatomegaly (mean bilirubin $\left.32 \mu \mathrm{mol} \cdot l^{-1}\right)$.

Table 1. - Clinical features of the patients $(n=20)$ with primary pulmonary hypertension

\begin{tabular}{|c|c|c|c|c|c|c|c|c|c|c|}
\hline $\begin{array}{l}\text { Case } \\
\text { No. }\end{array}$ & $\begin{array}{l}\text { Age } \\
\text { yrs }\end{array}$ & Sex & $\begin{array}{l}\text { Presenting } \\
\text { symptoms }\end{array}$ & $\begin{array}{r}\text { Additional } \\
\text { symptoms }\end{array}$ & $\begin{array}{c}\text { Disease } \\
\text { duration* yrs }\end{array}$ & RVF & RV-S3 & $\begin{array}{l}\text { Hepato- } \\
\text { megaly } \\
\mathrm{cm}\end{array}$ & TR & PR \\
\hline 1 & 4 & $\mathrm{~F}$ & $\mathrm{D}, \mathrm{C}$ & PS & 2 & + & - & 4 & - & - \\
\hline 2 & 8 & $\mathrm{~F}$ & $\mathrm{D}$ & $\mathrm{C}$ & 3 & - & - & & + & + \\
\hline 3 & 17 & $\mathrm{~F}$ & $\mathrm{D}, \mathrm{C}$ & PS & 13 & - & - & 8 & + & + \\
\hline 4 & 22 & $\mathrm{~F}$ & Asc & $\mathrm{D}, \mathrm{C}, \mathrm{PS}$ & 4 & + & + & 6 & + & + \\
\hline 5 & 24 & $\mathrm{~F}$ & $\mathrm{D}, \mathrm{S}$ & $\mathrm{C}, \mathrm{CP}$ & 2 & + & + & 4 & + & - \\
\hline 6 & 26 & $\mathrm{~F}$ & $\mathrm{D}, \mathrm{CP}$ & $\mathrm{C}$ & 8 & - & - & & - & + \\
\hline 7 & 28 & $\mathrm{~F}$ & Hpts & $\mathrm{D}, \mathrm{C}$ & 17 & - & - & 2 & - & - \\
\hline 8 & 29 & $\mathrm{~F}$ & $\mathrm{D}, \mathrm{C}$ & & 12 & - & + & 2 & + & - \\
\hline 9 & 32 & $\mathrm{~F}$ & $\mathrm{D}, \mathrm{M}$ & C, PS & 2 & + & + & 6 & + & - \\
\hline 10 & 34 & $\mathrm{~F}$ & $\mathrm{D}, \mathrm{CP}$ & & 1 & - & + & & + & - \\
\hline 11 & 36 & $\mathrm{~F}$ & D, Hpts & $\mathrm{C}$ & 6 & + & - & 7 & + & + \\
\hline 12 & 36 & $\mathrm{~F}$ & $\mathrm{D}, \mathrm{C}$ & & 10 & - & + & & + & - \\
\hline 13 & 45 & $\mathrm{~F}$ & $\mathrm{D}, \mathrm{Asc}$ & $\mathrm{CP}$ & 4 & + & + & 8 & + & - \\
\hline 14 & 51 & $\mathrm{~F}$ & D & $\mathrm{C}, \mathrm{CP}$ & 7 & - & + & & - & - \\
\hline 15 & 2 & M & $\mathrm{D}, \mathrm{C}$ & & 2 & - & - & & - & - \\
\hline 16 & 12 & M & S & $\mathrm{D}, \mathrm{CP}$ & 2 & + & + & 4 & + & - \\
\hline 17 & 21 & $\mathrm{M}$ & D & $\mathrm{CP}, \mathrm{PS}$ & 2 & - & - & & - & + \\
\hline 18 & 29 & M & $\mathrm{D}, \mathrm{C}$ & $\mathrm{S}, \mathrm{CP}$ & 0.3 & - & - & & + & - \\
\hline 19 & 30 & M & $\mathrm{D}, \mathrm{M}$ & $\mathrm{C}$ & 3 & + & + & 6 & + & + \\
\hline 20 & 39 & M & $\mathrm{D}$ & & 0.3 & $+* *$ & + & & - & - \\
\hline
\end{tabular}

*: onset to transplant; **: low output. RVF: right ventricular failure; RV-S3: right ventricular third heart sound; TR: tricuspid regurgitation; PR: pulmonary regurgitation; D: dyspnoea; S: syncope; C: cyanosis; Asc: ascites; PS: presyncope; CP: chest pain; M: malaise; Hpts: haemoptysis; +: present; -: absent; F: female; M: male. 
Cardiological. Electrocardiographic evidence of right atrial hypertrophy was present in 19 patients and right ventricular strain in all. The chest radiograph was normal in six, but showed cardiomegaly in the remaining 14 , and prominence of the hilar shadows in 12 . The echocardiograph was abnormal in every patient (table 2). In 12 patients, including all patients with right heart failure (as defined by elevated jugular venous pressure, peripheral oedema and ascites) the right ventricle was clearly larger than the left (Grade 3). The remaining eight patients were classified as Grade 2. Data obtained at cardiac catheterization are presented in table 2 . The mean pulmonary artery pressure for the group was 77 $\mathrm{mmHg}$, the mean pulmonary vascular resistance $29 \mathrm{mmHg}$. $l^{-1} \cdot \mathrm{min}$ and the mean cardiac output $2.4 l \cdot \mathrm{min}^{-1}$.

Response to vasodilators. Five patients had received prostacyclin in their referring centre, (commencing at 5 $\mathrm{ng} \cdot \mathrm{kg}^{-1} \cdot \mathrm{min}$, increasing to $20 \mathrm{ng} \cdot \mathrm{kg}^{-1} \cdot \mathrm{min}$, and continuing on this dose for $2 \mathrm{~h}$ ). All of these patients received a minimum of $15 \mathrm{~min}$ of $100 \%$ oxygen as a further test of reversibility. No patient demonstrated a therapeutic response to prostacyclin.

\section{Pathology}

Histopathology. The histological features of primary pulmonary hypertension were present in all subjects (table 3). Plexiform lesions were seen in 15 patients, being cellular in nine and mature in six. In the remaining five patients, intimal proliferation and/or muscularization of pulmonary arterioles and preplexiform changes were found; myofibroblasts were particularly obvious in the intima of small pulmonary arteries and arterioles in four of these cases, as well as in one patient with cellular plexiform lesions. Of the five patients who received prostacyclin, myofibroblasts were obvious in three and fibroblasts were present in the remaining two. Muscularization of pulmonary arterioles was noted in three of the five patients in the preplexiform group and in one of the nine patients in whom cellular plexiform lesions were observed, but was not found in those patients with mature plexiform lesions. Marked medial hypertrophy with thickening and crenation of elastic laminae, which were of equal thickness, was seen in muscular pulmonary arteries in four of the patients in the preplexiform stage, in five patients with cellular plexiform lesions, and in two patients with mature plexiform lesions, as well as in all patients who received prostacyclin. This appearance suggests possible sustained contraction during life. Thrombi were present in muscular pulmonary arteries in 13 patients. In 12 patients, atheroma of elastic pulmonary arteries was also present. The occurrence of thrombi and atheromatous lesions was independent of the presence or nature of plexiform lesions.

The proportion of luminal obstruction in pulmonary veins ranged from $0-36 \%$. It was more pronounced in patients with a longer duration of disease (Spearman's $r=0.52 ; p<0.01$ ). Furthermore, percentage luminal obstruction was related to the sex of the patient, the male mean of $10.5 \%$ being significantly lower than the female mean of $23.9 \%(\mathrm{p}<0.025)$.

Parenchymal haemorrhages of various ages were seen in 16 patients, and coexisted with infarction in eight. Pulmonary endocrine cells. There was a difference in the numbers of GRP and calcitonin-containing endocrine cells, when the 20 subjects studied were divided into two

Table 2. - Cardiac catheter and echocardiographic findings

\begin{tabular}{|c|c|c|c|c|c|c|c|c|}
\hline $\begin{array}{l}\text { Case } \\
\text { No. }\end{array}$ & $\begin{array}{c}\text { ECG P-wave } \\
\mathrm{mV}\end{array}$ & RVH & $\begin{array}{r}\text { Ppa,Sys } \\
\text { mmHg }\end{array}$ & $\begin{array}{c}\overline{\mathrm{P}} \mathrm{pa} \\
\mathrm{mmHg}\end{array}$ & $\begin{array}{c}\mathrm{PVR} \\
\mathrm{mmHg} \cdot l^{-1} \cdot \min \end{array}$ & $\begin{array}{c}\mathrm{S} \overline{\mathrm{V}} \mathrm{O}_{2} \\
\%\end{array}$ & $\begin{array}{l}\mathrm{CO} \\
l \cdot \mathrm{min}^{-1}\end{array}$ & $\begin{array}{l}\text { ECG } \\
\text { Grade }\end{array}$ \\
\hline 1 & 3 & + & 90 & 64 & 48 & 73 & 1.2 & 3 \\
\hline 2 & 4 & + & 112 & 67 & 21 & 69 & 2.7 & 3 \\
\hline 3 & 5 & + & 168 & 111 & 43 & 68 & 2.4 & 2 \\
\hline 4 & 6 & + & 95 & 61 & 25 & 70 & 2.0 & 3 \\
\hline 5 & 3 & + & 86 & 62 & 18 & 65 & 3.0 & 3 \\
\hline 6 & 3 & + & 94 & 76 & 30 & 58 & 2.1 & 2 \\
\hline 7 & 4 & + & 120 & 96 & 33 & 60 & 2.6 & 3 \\
\hline 8 & 2 & + & - & - & - & - & - & 2 \\
\hline 9 & 3 & + & 100 & 61 & 24 & 60 & 2.1 & 3 \\
\hline 10 & 3 & + & 100 & 70 & 24 & 70 & 2.4 & 2 \\
\hline 11 & 3 & + & 100 & 80 & 28 & 55 & 2.5 & 3 \\
\hline 12 & 3 & + & 132 & 87 & 29 & 68 & 2.6 & 2 \\
\hline 13 & 4 & + & 90 & 50 & 14 & 69 & 2.9 & 3 \\
\hline 14 & 3 & + & 120 & 65 & 20 & 61 & 2.4 & 2 \\
\hline 15 & 3 & + & - & - & - & - & - & 2 \\
\hline 16 & 4 & + & 140 & 90 & 40 & 71 & 2.1 & 3 \\
\hline 17 & 3 & + & 115 & 84 & 29 & 35 & 2.3 & 3 \\
\hline 18 & 4 & + & 101 & 64 & 28 & 66 & 2.1 & 2 \\
\hline 19 & 4 & + & 140 & 100 & 22 & 66 & 4.2 & 3 \\
\hline 20 & 4 & + & 118 & 98 & 53 & 58 & 1.7 & 3 \\
\hline
\end{tabular}

ECG: echocardiographic; RVH: right ventricular hypertrophy; Ppa,sys: pulmonary arterial systolic pressure; $\bar{P}$ pa: mean pulmonary arterial pressure; PVR: pulmonary vascular resistance; $\mathrm{S}_{\bar{v}}{ }_{2}$ : pulmonary mixed venous oxygen saturation; CO: cardiac output; -: cardiac catheter data not available; +: present. 
Table 3. - Histopathological changes and pulmonary endocrine cell counts

\begin{tabular}{|c|c|c|c|c|c|c|c|c|c|c|}
\hline \multirow[t]{2}{*}{$\begin{array}{l}\text { Case } \\
\text { No. }\end{array}$} & \multirow[t]{2}{*}{$\begin{array}{l}\text { Vasodilator } \\
\text { challenge }\end{array}$} & \multirow{2}{*}{$\begin{array}{c}\text { Presence \& } \\
\text { nature of } \\
\text { plexiform } \\
\text { lesions }\end{array}$} & \multirow{2}{*}{$\begin{array}{l}\text { Nature of } \\
\text { intimal } \\
\text { proliferation } \\
\text { in MPA }\end{array}$} & \multirow{2}{*}{$\begin{array}{c}\text { Presence \& } \\
\text { characteri- } \\
\text { zation of } \\
\text { vessels } \\
<80 \mu \mathrm{m} \\
\text { diameter }\end{array}$} & \multirow{2}{*}{$\begin{array}{l}\text { Presence } \\
\text { of thrombi } \\
\text { in MPA }\end{array}$} & \multirow{2}{*}{$\begin{array}{l}\text { Severity } \\
\text { of } \\
\text { athero- } \\
\text { sclerosis }\end{array}$} & \multirow{2}{*}{$\begin{array}{l}\text { Luminal } \\
\text { obstruction } \\
\text { in veins } \\
\%\end{array}$} & \multirow{2}{*}{$\begin{array}{l}\text { Presence of } \\
\text { haemorrhage } \\
\text { or } \\
\text { infarction }\end{array}$} & \multicolumn{2}{|c|}{$\begin{array}{l}\text { Endocrine cells } \\
\text { immunoreactive for }\end{array}$} \\
\hline & & & & & & & & & GRP & $\begin{array}{l}\text { Calcitonin } \\
1 \mathrm{~s} \cdot \mathrm{cm}^{-2}\end{array}$ \\
\hline 1 & $\mathrm{P}$ & 0 & MFB & $\mathrm{Ca}, \mathrm{Ma}$ & 0 & 0 & 0 & $\mathrm{H}$ & 167 & 11 \\
\hline 2 & $\mathrm{P}$ & 0 & MFB & $\mathrm{Ca}$ & + & +++ & 10 & $\mathrm{H}$ & 70 & 11 \\
\hline 3 & 0 & $\mathrm{C}$ & LM & $\mathrm{Ca}$ & ++ & ++ & 21 & $\mathrm{H}, \mathrm{I}$ & 21 & 0 \\
\hline 4 & $\mathrm{P}$ & 0 & MFB & $\mathrm{Ca}, \mathrm{Ma}$ & + & + & 23 & $\mathrm{H}$ & 96 & 17 \\
\hline 5 & $\mathrm{P}$ & M & FE, LM & $\mathrm{Ca}$ & ++ & ++ & 29 & 0 & 26 & 5 \\
\hline 6 & 0 & $\mathrm{C}$ & FE, LM & 0 & 0 & 0 & 36 & $\mathrm{H}, \mathrm{I}$ & 2 & 0 \\
\hline 7 & 0 & M & $\mathrm{FE}$ & 0 & 0 & +++ & 21 & $\mathrm{H}, \mathrm{I}$ & 1 & 0 \\
\hline 8 & 0 & M & FE, LM & 0 & ++ & + & 36 & $\mathrm{H}, \mathrm{I}$ & 45 & 2 \\
\hline 9 & 0 & 0 & MFB, LM & $\mathrm{Ca}$ & + & 0 & 30 & $\mathrm{H}$ & 45 & 3 \\
\hline 10 & 0 & $\mathrm{C}$ & LM & 0 & 0 & ++ & 12 & $\mathrm{H}$ & 6 & 1 \\
\hline 11 & 0 & M & FE, LM & 0 & ++ & + & 21 & $\mathrm{H}$ & 10 & 1 \\
\hline 12 & $\mathrm{P}$ & $\mathrm{C}$ & FE, LM & $\mathrm{Ca}$ & + & ++ & 28 & 0 & 33 & 9 \\
\hline 13 & 0 & $\mathrm{C}$ & FE,LM & 0 & + & ++ & 25 & $\mathrm{H}, \mathrm{I}$ & 50 & 3 \\
\hline 14 & 0 & 0 & CSM, LM & $\mathrm{Ma}$ & 0 & + & 36 & $\mathrm{H}, \mathrm{I}$ & 3 & 0 \\
\hline 15 & 0 & $\mathrm{C}$ & MFB & $\mathrm{Ca}, \mathrm{Ma}$ & 0 & 0 & 0 & 0 & 108 & 23 \\
\hline 16 & 0 & $\mathrm{C}$ & CSM, LM & $\mathrm{Ca}$ & 0 & + & 21 & 0 & 22 & 0 \\
\hline 17 & 0 & $\mathrm{M}$ & $\mathrm{FE}$ & 0 & + & ++ & 11 & $\mathrm{H}, \mathrm{I}$ & 52 & 8 \\
\hline 18 & 0 & $\mathrm{C}$ & FE, LM & $\mathrm{Ca}$ & +++ & ++ & 11 & $\mathrm{H}, \mathrm{I}$ & 26 & 2 \\
\hline 19 & 0 & M & FE, LM & $\mathrm{Ca}$ & + & + & 10 & $\mathrm{H}$ & 10 & 2 \\
\hline 20 & 0 & $\mathrm{C}$ & FE, LM & 0 & +++ & +++ & 16 & $\mathrm{H}$ & 9 & 2 \\
\hline
\end{tabular}

C: cellular plexiform lesions; Ca: contracted small muscular pulmonary arteries; CSM: circular smooth muscle; FE: fibroelastosis; GRP: gastrin-releasing peptide; H: haemorrhage; I: infarction; LM: longitudinal smooth muscle; M: mature plexiform lesions; Ma: muscularized arterioles; MFB: myofibroblast; MPA: muscular pulmonary arteries; P: prostacyclin; 0: absent;,,++++++ : positive graded.

groups according to activity of myofibroblasts. In the five patients with active migration of myofibroblasts, the number of cells immunoreactive for GRP averaged 97 cells $\cdot \mathrm{cm}^{-2}$ of tissue section, compared with 21 cells $\cdot \mathrm{cm}^{-2}$ of tissue section in the 15 patients in whom activity of myofibroblasts was not observed. This difference is highly significant $(p<0.001)$. Similarly, the number of cells immunoreactive for calcitonin averaged $13 \cdot \mathrm{cm}^{-2}$ of tissue section in those patients in whom myofibroblasts were evident, compared with 2.3 cells $\cdot \mathrm{cm}^{-2}$ of tissue section in those in whom myofibroblasts were not seen. Once again, the difference in numbers of endocrine cells is highly significant $(\mathrm{p}<0.001)$. There was no statistically significant difference between the numbers of pulmonary endocrine cells in patients with cellular plexiform lesions (without myofibroblasts) when compared with those patients with mature plexiform lesions. In pulmonary tissue assessed identically, but from four control subjects with a mean age of 6 yrs, there were means of 11 endocrine cells $\cdot \mathrm{cm}^{-2}$ of tissue section immunoreactive for GRP, and just 1 cell $\cdot \mathrm{cm}^{-2}$ immunoreactive for calcitonin. In a group of four subjects with a mean age of $24 \mathrm{yrs}$, corresponding counts were 10 and 1 cells $\cdot \mathrm{cm}^{-2}$.

Ultrastructure. Electron microscopy did not reveal muscular evaginations in any case.

\section{Clinicopathological correlation}

Using multivariate regression analysis, no clinical feature was strongly predictive of any histological finding. Age and sex had no relationship to histopathology. Short duration of disease, low pulmonary vascular resistance, low pulmonary systolic arterial pressure, absence of cyanosis or right ventricular failure and Grade 2 echocardiogaphic changes were not predictive of an early (preplexiform) histopathology. Likewise, a long history or clinical indices of severe disease was not necessarily predictive of advanced (mature plexiform lesions) histopathology.

However, there was a statistically significant inverse relationship between mean pulmonary artery pressure and numbers of pulmonary endocrine cells immunoreactive for GRP, (Spearman's $r=-0.51 ; \mathrm{p}<0.025)$ and for mean pulmonary artery pressure and numbers of cells immunoreactive for calcitonin, (Spearman's $r=-0.51$, $\mathrm{p}<0.025)$. There was a correlation between numbers of calcitonin immunoreactive cells and pulmonary arterial systolic pressure (Spearman's $r=-0.47 ; \mathrm{p}<0.025)$. In addition, there was a correlation between numbers of calcitonin immunoreactive cells and mixed venous oxygen saturation $\left(\mathrm{S}_{\bar{v}} \mathrm{O}_{2}\right)$ (Spearman's $\left.\mathrm{r}=+0.44 ; \mathrm{p}<0.05\right)$ and between pulmonary arterial systolic pressure and $\mathrm{S}_{\bar{v}} \mathrm{O}_{2}$ (Spearman's $\mathrm{r}=-0.41 ; \mathrm{p}<0.05$ ).

\section{Discussion}

Our study clearly demonstrates that similar degrees of disability due to primary pulmonary hypertension may occur despite wide variations in pulmonary vascular resistance, evidence of right ventricular impairment and histopathological grading of disease. Furthermore, the spectrum of these findings cannot be explained in terms of the rate of disease progression, age or sex, or the occurrence of secondary events, such as right heart failure. Although no particular clinical features were predictive of any histological appearance, duration of disease 
did correlate with more marked occlusion of pulmonary veins, possibly representing adaptation to sustained elevation of pulmonary arterial pressure.

We appreciate that the correlation between pulmonary haemodynamic data and pulmonary structure are limited by the fact that some of the haemodynamic data had been obtained as long as 2 yrs prior to transplantation. Unfortunately, due to the limited availability of donor organs, it is not possible to predict when patients will be transplanted once they are placed on the transplant waiting list. As all patients in the present study had endstage disease, repeating cardiac catheterization studies would not have been without risk to the patient and would not have provided additional beneficial information.

Mortality in primary pulmonary hypertension is related to elevation in mean right atrial and mean pulmonary arterial pressures, decreased cardiac index, Raynaud's phenomenon and a New York Heart Association functional class III or IV [14]. All of our patients who had cardiac catheterization had markedly elevated mean pulmonary arterial pressure (mean for the group, $77 \mathrm{mmHg}$ ) and pulmonary vascular resistance (mean for the group, $29 \mathrm{mmHg} \cdot l^{-1} \cdot \mathrm{min}$ ) and, with the exception of patient No. 19 , markedly decreased cardiac outputs (group mean 2.4 $l \cdot \mathrm{min}^{-1}$ ). Two patients had Raynaud's phenomenon. It is clear, therefore, that this group represents patients with very advanced disease and a poor prognosis. It is appreciated that data from this group cannot necessarily be extrapolated to primary pulmonary hypertension in general.

It has generally been believed that the initial cause of the elevated pressure in primary pulmonary hypertension is vasoconstriction, followed by medial hypertrophy of muscular pulmonary arteries and muscularization of arterioles. The increased quantity of muscle is then believed to permit more forceful contraction, leading to further rises in pulmonary vascular resistance. Clinical evidence used to support this contention includes the documented response to vasodilator therapy in a significant proportion of patients with the disease $[15,16]$.

The presence of contracted muscular pulmonary arteries was not associated with responsiveness to vasodilator therapy. In previous studies of the pulmonary vasculature of patients with plexogenic pulmonary arteriopathy [5], we have been able to define muscular arterial vessels less than $80 \mu \mathrm{m}$ in diameter, in which a thick muscular media is sandwiched between crenated elastic laminae of equal thickness. We have no doubt that these are contracted muscular arteries. They do not resemble muscularized arterioles, except in their diameter, and we have never seen them in collapsed lungs from patients without pulmonary vascular pathology.

Clearly, the patients in the present group may have had disease so advanced that a response to vasodilator therapy was no longer possible, despite the presence of contracted small muscular pulmonary arteries, a possibility supported by the observation that none had ultrastructural evidence of muscular evaginations. This suggests that some process additional to vasoconstriction is occurring in these vessels, possibly intimal proliferation, which might produce progressive occlusion, leading to a rise in pulmonary vascular resistance. Indeed, several studies indicate that migration of smooth muscle cells plays an important role in the remodelling of the pulmonary vasculature that occurs in primary pulmonary hypertension [4-7]. Active myofibroblasts are believed to be modified smooth muscle cells derived from the inner half of the media of muscular pulmonary arteries [4], and which can differentiate either to smooth muscle cells or to fibroblasts.

Myofibroblasts were found in five patients in the study group, in four with preplexiform and in one with cellular plexiform lesions. They were present in three of the five patients who received prostacyclin. The remaining patients had intimal fibroelastosis and longitudinal smooth muscle. The lack of responsiveness to vasodilator therapy in these patients may have been attributable to functional occlusion to blood flow or reduced vascular compliance in the muscular pulmonary arteries secondary to intimal proliferation.

The previously reported association between stage of plexogenic pulmonary arteriopathy and numbers of pulmonary endocrine cells [6-9] has been confirmed in the present study. High cell counts were almost invariable in those patients in whom myofibroblasts were in evidence, and were low in those in whom these cells were not observed but in whom plexiform lesions had developed, and it has been suggested that GRP may be involved in stimulating smooth muscle migration $[4,6]$. A statistically significant inverse relationship was also noted between the numbers of pulmonary endocrine cells and mean pulmonary artery pressure. Thus, mean pulmonary artery pressure tended to be lower in those patients with high cell counts and vice versa.

In this study, a group of patients with end-stage primary pulmonary hypertension has been shown to display a wide range of clinical haemodynamic and pathological characteristics, indicating that prognosis of disease cannot yet be defined other than by its clinical manifestations. Vasodilators were uniformly unsuccessful in the patients studied, but certain histopathological and endocrinological findings, which are consistent with the migratory theory of the pathogenesis of primary pulmonary hypertension, raise therapeutic implications. Vasodilators are unlikely to produce beneficial effects in patients in whom intimal proliferation has occurred to produce functional occlusion to blood flow and, thereby, elevate the pulmonary vascular resistance. They would, however, appear to be of major benefit to those in whom vasoconstriction predominates, or in the early stages of the disease before intimal proliferation has occurred. Should further studies confirm that smooth muscle migration contributes to disease progression in this condition, treatment with agents known to inhibit or retard it, such as ligustrazine [17], might prove to be useful in its management.

Acknowledgement: The authors are grateful to M. Rehahn for statistical advice.

\section{References}

1. Fishman AP, Pietra GG. Primary pulmonary hypertension. Ann Rev Med 1980; 31: 421-431. 
2. Wagenvoort CA, Wagenvoort N. Primary pulmonary hypertension. A pathologic study of the lung vessels in 156 clinically diagnosed cases. Circulation 1970; 42: 1163-1184.

3. Heath D, Edwards JE. The pathology of hypertensive pulmonary vascular disease. A description of six grades of structural changes in the pulmonary arteries with special reference to congenital cardiac septal defects. Circulation 1958; 18: 533-547.

4. Heath D, Smith P, Gosney J, et al. The pathology of the early and late stages of primary pulmonary hypertension. Br Heart J 1987; 58: 204-213.

5. Caslin AW, Heath D, Madden B, Yacoub M, Gosney JR, Smith P. The histopathology of 36 cases of plexogenic pulmonary arteriopathy. Histopathol 1990; 16: 9-19.

6. Heath D, Smith P, Gosney J. Ultrastructure of early plexogenic pulmonary arteriopathy. Histopathol 1988; 12: 41-52.

7. Smith P, Heath D, Yacoub M, Madden B, Caslin AW, Gosney JR. The ultrastructure of plexogenic pulmonary arteriopathy. J Pathol 1990; 160: 111-121.

8. Gosney J, Heath D, Smith P, Harris P, Yacoub M. Pulmonary endocrine cells in pulmonary arterial disease. Arch Pathol Lab Med 1989; 113: 337-341.

9. Heath D, Yacoub M, Gosney J, Madden B, Caslin A, Smith P. Pulmonary endocrine cells in hypertensive pulmonary vascular disease. Histopathol 1990; 16: 21-28.
10. Dresdale DT, Schultz M, Michtom RJ. Primary pulmonary hypertension. Clinical and haemodynamic study. Am J Med 1951; 11: 686-705.

11. Fuster V, Steele P, Edwards W, Gersh B, McGoon M, Frye R. Primary pulmonary hypertension: natural history and the importance of thrombosis. Circulation 1984; 70: $580-587$.

12. Gosney JR. Pulmonary endocrine pathology: endocrine cells and endocrine tumours of the lung. Oxford, Butterworth Heinemann, 1992.

13. Fay FS, Delise CM. Contraction of isolated smooth muscle cells: structural changes. Proc Natl Acad Sci USA 1973; 70: 641-645.

14. D'Alonzo GE, Barst RJ, Ayres SM, et al. Survival in patients with primary pulmonary hypertension. Results from a National Prospective Registry. Ann Intern Med 1991; 115: 343-349.

15. Simmoneau G, Herbe P, Pepitpretz P, et al. Detection of a reversible component in primary pulmonary hypertension; value of prostacyclin acute infusion. Am Rev Respir Dis 1986; 133: A223.

16. Jones DK, Higenbottam T, Wallwork J. Treatment of primary pulmonary hypertension with intravenous epoprostenol (prostacyclin). Br Heart J 1987; 57: 270-278.

17. Oddoy A, Bee D, Emery C, Barer G. Effect of ligustrazine on the pressure/flow relationship in isolated perfused rat lungs. Eur Respir J 1991; 4: 1223-1227. 